\title{
Algorithms for prevention and treatment of incontinence-associated dermatitis
}

\section{Algoritmos para prevenção e tratamento de dermatite associada à incontinência}

\section{Algoritmos para la prevención y el tratamiento de la dermatitis asociada a la incontinencia}

\author{
Geraldo Magela Salomé ${ }^{*}$, Cleber Aparecido da Rocha ${ }^{1}$, Flávio Dutra Miranda ${ }^{1}$, José Ronaldo \\ Alves ${ }^{1,2}$, Rosimar Aparecida Alves Dutra ${ }^{1,3}$, Amanda Gabriele Tenório ${ }^{4}$
}

ORCID IDS

Salomé GM (D) https://orcid.org/0000-0002-7315-4866

Rocha CA (D) https://orcid.org/0000-0002-6558-5375

Miranda FD (D) http://orcid.org/0000-0002-1631-0164

Alves JR (D) https://orcid.org/0000-0002-4255-8884

Dutra RAA (D) https://orcid.org/0000-0001-9080-4800

Tenório AG (D) https://orcid.org/0000-0002-5016-1713

\begin{abstract}
HOW TO CITE
Salomé GM; Rocha CA; Miranda FD; Alves JR; Dutra RAA; Tenório AG. Algoritmos para prevenção e tratamento de dermatite associada à incontinência. ESTIMA, Braz. J. Enterostomal Ther., 18, 2020: e1320. https://doi.org/10.30886/estima.v18.837_IN
\end{abstract}

\begin{abstract}
Objective: To build and validate algorithms for prevention and treatment of incontinence-associated dermatitis. Method: A methodological study. An integrative review of articles published from 2009 to 2019 was carried out after a literature search in the main Health Sciences databases for the construction of the algorithms. The algorithms were evaluated by 27 nurses using the Delphi technique. The content validity index was used for data analysis. Results: The judges evaluated the algorithms from inadequate to adequate in the first round of consultation, and from adequate to totally adequate in the second round of consultation. The global content validity index was 0.923 in the first consultation and 1.0 in the second consultation. Conclusion: After reviewing the literature, the algorithms were constructed and validated by professionals with experience in the area, reaching agreement among the judges in the second round of consultation.
\end{abstract}

DESCRIPTORS: Skin care; Dermatitis; Diaper rash; Enterostomal therapy.

\begin{abstract}
RESUMO
Objetivo: Construir e validar algoritmos para a prevenção e o tratamento da dermatite associada à incontinência. Método: Estudo metodológico. Para o desenvolvimento dos algoritmos, foi realizada revisão integrativa de artigos publicados de 2009 a 2019 encontrados nas principais bases de dados em ciências da saúde. A avaliação dos algoritmos foi realizada com 27 enfermeiros, utilizando a técnica de Delphi. Para a análise de dados, foi adotado o índice de validade de conteúdo. Resultados: Os juízes consideraram os algoritmos entre inadequados e adequados na primeira avaliação e entre adequados e totalmente adequados na segunda avaliação. O índice de validade de conteúdo geral foi de 0,923 na primeira avaliação e 1,0 na segunda avaliação. Conclusão: Após revisão da literatura, os algoritmos foram construídos e validados por profissionais com experiência na área, obtendo concordância entre os juízes na segunda avaliação.
\end{abstract}

DESCRITORES: Higiene da pele; Dermatite; Dermatite das fraldas; Estomaterapia.

\footnotetext{
1. Universidade do Vale do Sapucaí - Faculdade de Ciências Médicas Dr. José Antônio Garcia Coutinho - Pouso Alegre (MG), Brazil.

2. Santa Casa de Misericórdia de Passos - Departamento de Cardiologia - Passos (MG), Brazil.

3. Santa Casa de Misericórdia de Passos - Ambulatório de Estomaterapia - Passos (MG), Brazil.

4. Universidade do Vale do Sapucaí - Faculdade de Ciências Médicas Dr. José Antônio Garcia Coutinho - Escola de Enfermagem Pouso Alegre (MG), Brazil.
}

*Correspondence author: salomereiki@univas.edu.br

Received: Dec. 22, 2019 | Accepted: Apr. 20, 2020 


\section{RESUMEN}

Objetivo: Construir y validar algoritmos para la prevención y el tratamiento de la dermatitis asociada a la incontinencia. Método: Estudio metodológico. Para la construcción de los algoritmos, se realizó una revisión integradora de artículos publicados de 2009 a 2019 encontrados en las principales bases de datos de Ciencias de la Salud. Los algoritmos fueron evaluados por 27 enfermeras utilizando la técnica Delphi. Para el análisis de datos, se adoptó el índice de validez de contenido. Resultados: Los jueces evaluaron los algoritmos de inadecuados a adecuados en la primera evaluación, y de adecuados a totalmente adecuados en la segunda evaluación. El índice general de validez de contenido fue de 0.923 en la primera evaluación y 1.0 en la segunda evaluación. Conclusión: Después de la revisión de la literatura, los algoritmos fueron construidos y validados por profesionales con experiencia en el área, mostrando un acuerdo entre los jueces en la segunda evaluación.

DESCRIPTORES: Cuidados de la piel; Dermatitis; Dermatitis del pañal; Estomaterapia.

\section{INTRODUCTION}

To repair tissue damage, the body uses intrinsic, dynamic, organized, and extremely complex biological processes that can be rapid when the clinical situation is favorable and the extent and degree of tissue loss is reduced. However, several wounds become chronic and negatively affect the individual's life in all aspects, leading to a series of problems, such as pain, changes in selfesteem, self-image and spirituality, reducing the quality of life and causing shame, embarrassment in social living and functional commitment ${ }^{1-4}$.

It is important to emphasize that, during hospitalizations in hospital units and long-stay institutes, some specific types of skin injuries may occur, such as incontinence-associated dermatitis (IAD). It is essential that the nurse knows these types of injuries and their specificities in order to plan the assistance properly, with minimum risk, without damage and adverse events ${ }^{5-7}$.

The incontinence-associated dermatitis is defined as an area of erythema and edema of the skin surface, sometimes accompanied by bullous lesions with exudate, erosion or secondary skin infection, which is related to a variety of clinical disorders due to excessive exposure to effluents such as urine, feces, perspiration, wound exudate, among others ${ }^{8}$.

The prevalence of IAD was characterized in several national and international studies as responsible for $7 \%$ of skin lesions in incontinent patients admitted to nursing homes; $50 \%$ of these lesions were detected in patients with fecal incontinence; whereas $42 \%$ were in adult patients with incontinence who were hospitalized and $83 \%$ of incontinent patients who were admitted to intensive care units ${ }^{8-11}$.
For this reason, nurses should assess the patient's skin at the time of admission and, from then on, daily; they should also guide the professionals involved and the caregivers who care for these individuals to keep the skin dry and clean by maintaining body hygiene and diaper changes after the patient urinates and evacuates ${ }^{7,12-15}$. These instructions can be given in the form of oral or written guidance. It is also important to develop educational material such as algorithms, primers, protocols, applications and online courses, among others, on the care and prevention of IAD complications.

Algorithms consist of a finite sequence of well-defined instructions performed systematically. They are commonly applied in the health field; they are simple, direct and easily accessible instruments that give a complete view of the clinical process. They are also an indispensable tool in the standardization of techniques and quality management, constituting an important tool for the organization of processes that serves as a guide for decision making ${ }^{13,14}$.

Algorithms developed for prevention and treatment of IAD can contribute to an objective evaluation of the characteristics of the area examined, in the prescription of preventive measures and therapeutic conducts, besides facilitating the registration of the characteristics of DAI detected in the patients, ensuring the monitoring of the evolution of the injury, minimizing risks, damages and adverse events.

The validation of an algorithm is an important process, as it determines whether the instrument is adequate to provide analytical measures and information appropriate to a given objective and contex $\mathrm{t}^{15}$ as an assessment of the presence of risk factors for IAD and guidelines for the prevention and treatment of this condition, among other factors. Validated algorithms enable individualized and systematized care and the optimization of decision 
making that have as consequence the reduction of costs with the care provided by health services and the provision of assistance with quality and safety ${ }^{13,16}$.

This study aimed to develop and validate algorithms for the prevention and treatment of IAD.

\section{METHODS}

Methodological study of descriptive character developed through the opinion of a group of specialists. The process of building the algorithms took place between the months of May and December 2017, and the validation of the algorithms by experts, between January and April 2018. This study was approved by the Research Ethics Committee of the Faculdade de Ciências da Saúde "Dr.José Antônio Garcia Coutinho” from Universidade do Vale do Sapucaí (UNIVÁS), Pouso Alegre/MG, under the opinion consubstantiated n. CAAE 51545915.3.0000.5102.

For the construction of algorithms for the prevention and treatment of IAD, an integrative review was carried out in the health sciences databases, including the Cochrane Library, Scientific Electronic Library (SciELO), Latin American and Caribbean Literature in Health Sciences (LILACS), Online Medical Literature Search and Analysis System (MEDLINE), International Nursing Index (INI), and Cumulative Index to Nursing and Allied Health Literature (CINAHL) in articles published from 2009 to 2019 in Portuguese, English and Spanish. The descriptors "diaper dermatitis", "skin hygiene", "dermatitis" and "enterostomal therapy" were used, as well as their combinations in Portuguese, Spanish and English.

To select the content of publications to be included in the construction of the algorithms, only primary studies that had a direct link to the subject and were available in full and without temporal delimitation were adopted as inclusion criteria, since the intention was to compile all studies that met the established criteria.

Algorithms for the prevention and treatment of incontinence associated dermatitis were developed in three steps, following criteria adapted from previous studies ${ }^{7-12}$.

The first stage involves skin assessment in the genital, perigenital and intimate perineal areas, with anamnesis, physical examination, application of the perineal assessment tool and identification of risk factors for the individual to acquire the IAD.
The second stage covers the standardization of care and products to be used daily in hygiene in the genital, perigenital and intimate perineal regions and the preventive measures of IAD. These preventive measures were constructed according to the results of physical examination, anamnesis and the results of the perineal assessment tool scale.

The third stage presents the standardization of therapeutic conducts to be used for the treatment of $\mathrm{IAD}$, correct sequence and use of appropriate products in hygiene in the genital, perigenital and perineal areas. The therapeutic procedures were constructed according to the results of the evaluation in the genital, perigenital and perineal areas and the results of the perineal assessment tool scale.

The validation of the algorithms began after their construction by a group of 27 specialists. Participated in the study nurses who work in wound treatment at UNIVÁS, Hospital de Clínicas Samuel Libânio, postgraduated nurses in enterostomal therapy registered in the Brazilian Association of Enterostomal Therapy and dermatology nurses registered in the Brazilian Association of Dermatology Nursing.

The inclusion criteria of the evaluators were: professionals graduated in Nursing, with at least one year of experience in the treatment of patients with wounds. The exclusion criteria for the evaluators referred to the professionals who agreed to participate in the study, but did not answer and/ or submit the evaluation questionnaire within 15 days.

An invitation letter was sent by e-mail or delivered by hand to the evaluators for validation of the algorithms, containing: initial personal presentation and elucidations on the subject of the research, opinion of the Institutional Research Ethics Committee, explanations on the importance of the professional evaluator in the research; and a step-bystep approach for the effective participation of the evaluator. A period of 15 days from the day the invitation was sent out has been stipulated for completing the questionnaire and forwarding the answers.

The questionnaire for evaluation and validation of the algorithms for prevention and treatment of IAD was built in two parts. The first part addressed the identification of evaluators on seven issues related to: time of graduation, gender, age, type of undergraduate course, whether a graduate course (i.e., specialization, master's or doctorate), length of experience in teaching, and length of experience in attendance. 
The second part of the questionnaire was designed to evaluate and validate the algorithms according to the Delphi technique and contained 11 multiple choice questions related to: graphical presentation, ease of reading, vocabulary, sequence of algorithms, preventive measures and treatment of the IAD, description of the risk factors for the patient to acquire the IAD and type of coverage to treat it.

For the evaluation of the algorithms, the 11 questions were answered using a Likert scale. The responses that the judges marked were rated as "adequate", "fully adequate", "inadequate", "partially adequate" and "not applicable". Responses classified as "inadequate", "partially adequate" and "not applicable" were not excluded. For these issues, the corrections suggested by the judges were made and the algorithms were sent back to a second round with a new review by the judges. The validation was completed after reaching $100 \%$ consensus of approval among the judges.

The Delphi technique is a method of evaluating an instrument by a group of evaluators who are experts in the field in search of a consensus between 80 and 100\% among the evaluators. The anonymity of the evaluators should be maintained. The instrument should be changed based on relevant suggestions made by the evaluators and the researcher should send the corrected instrument to the evaluators for reevaluation until a consensus is reached ${ }^{17,18}$.

Once consensus among the evaluators was reached, statistical analysis was performed for the validity of content using the content validity index. Algorithms with a general content validity index value of 0.90 or higher were considered validated. The items that obtained a percentage below $90 \%$ of agreement were reformulated based on the experts' suggestions and the scientific literature ${ }^{19}$.

\section{RESULTS}

The search in health sciences databases resulted in 538 articles, from which 38 were selected for inclusion in the study. The flowchart showing the article selection process is shown in Fig. 1. After the integrative literature review, two algorithms were developed: an algorithm for the patient's clinical evaluation for IAD (Fig. 2) and another that indicates procedures for prevention and treatment of IAD (Fig. 3).
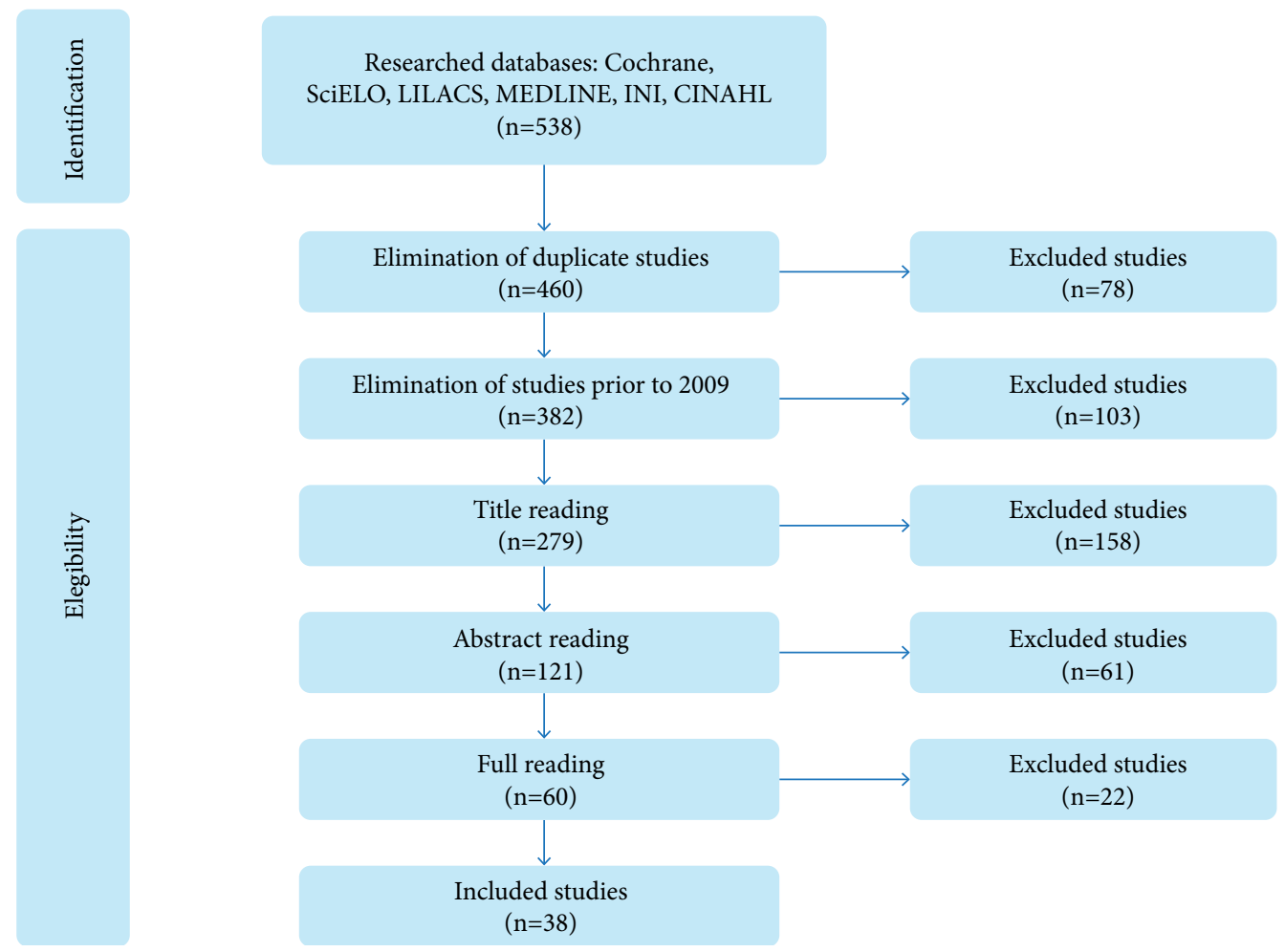

Figura 1. Flow chart of the selection process of studies used in the development of algorithms for clinical evaluation, prevention and treatment of incontinence-associated dermatitis. Pouso Alegre, MG, Brazil, 2019. 


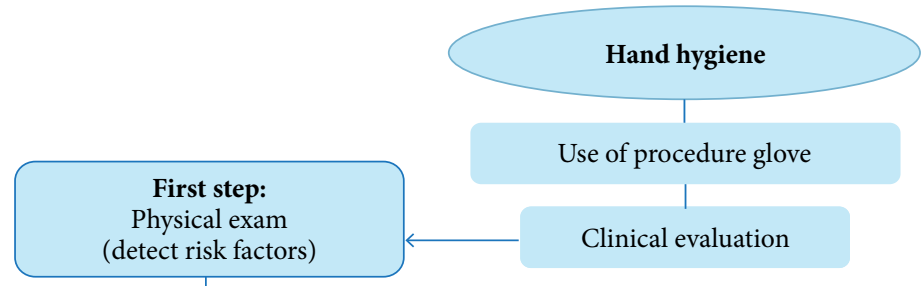

Age; Ointments and oils; Skin deterioration due to aging; Bladder weakness; Increased local $\mathrm{pH}$ in the pubic area; Urinary and/or fecal incontinence; Exposure to humidity; Excessive perspiration; Time and frequency of skin exposure to urine and feces; Constant use of soaps, ointments and oils; Enteral diet; Use of incorrect products; Use of disposable diapers; Skin rubbing during hygiene.

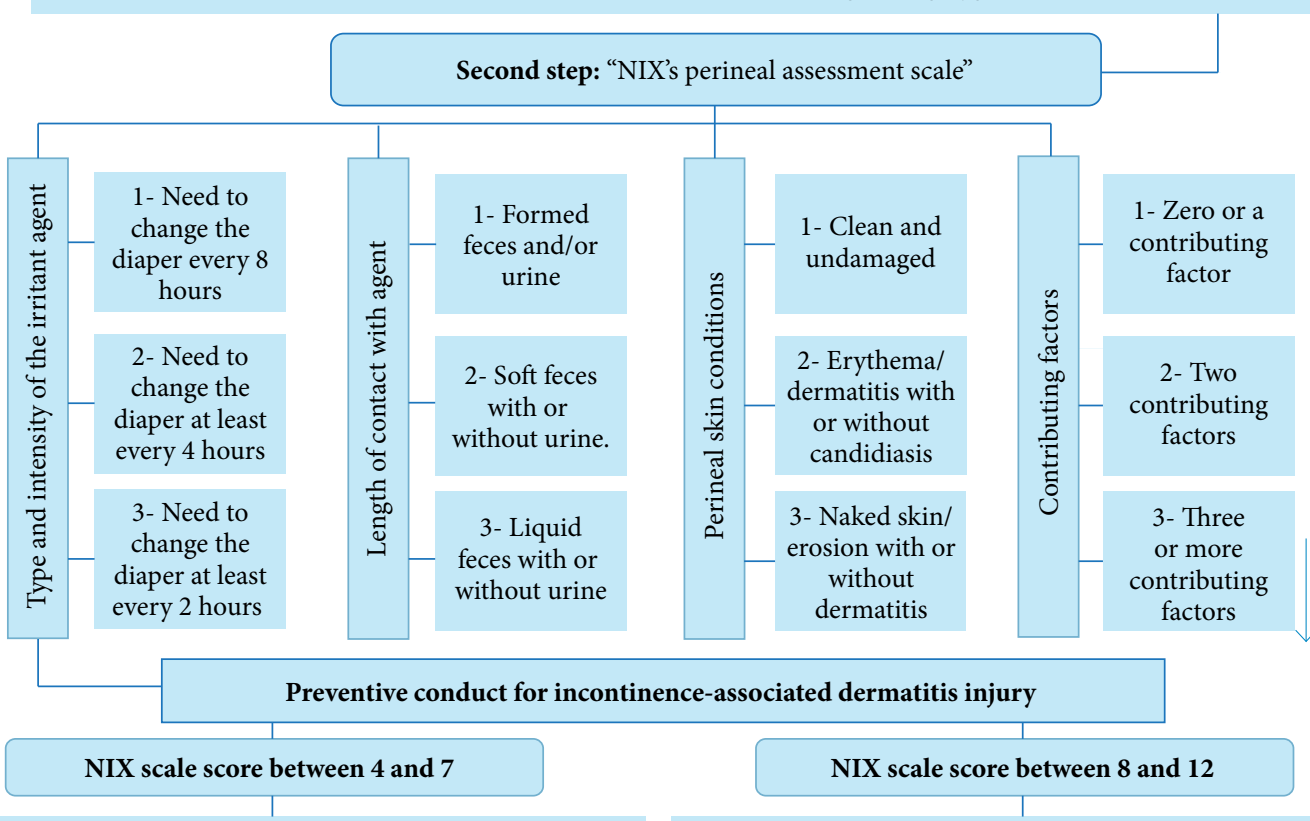

Type and intensity of the irritant agent

Use urinary collectors, bedpan or handheld urinals.

Duration of contact with the irritant agent

Guide patients with preserved cognitive to warn professionals when they are wet. Adjust the size of the diaper to the patient. Avoid cloth diapers. Pay attention to the frequency of diaper change, so as not to extrapolate the absorption capacity. Change the diaper with feces immediately. Keep sheets clean and dry.

Perineal skin conditions

Assess the patient's skin daily. Keep the skin clean and dry. Trim the pubic hair. Use cotton compresses or alcohol-free wet wipes. Use liquid soap with neutral $\mathrm{pH}$ and warm water. Dry skin gently with small touches (without rubbing), with special attention to skin folds. Gently apply protective creams based on dimeticone.

Duration of contact with the irritant agent

Use nonocclusive absorbent diapers that do not inhibit perspiration. Check the patient's diaper at each decubitus change.

Perineal skin conditions

Assess the patient's skin daily. Keep the skin clean and dry. Trim the pubic hair. Use cotton compresses or alcohol-free wet wipes. Use liquid soap with slightly acidified $\mathrm{pH}$ (near 5.5) and warm water. Dry the skin gently with small touches (without rubbing), with special attention to the skin folds. Gently apply protective creams based on dimeticone. Combine polymeric spray film up to $48 / 48 \mathrm{~h}$. Position the patient, if possible, three times a day for 30 minutes, for exposure of the skin to ambient air. Pay attention to other sources of humidity, such as leakage of drain fluids on the skin, wound exudate, perspiration and lymph spillage

Figure 2. Algorithm for clinical assessment of the patient for incontinence associated dermatitis. Pouso Alegre, MG, Brazil, 2019.

Among the 27 nurses who participated in the study (judges), 10 (37\%) had from 1 to 10 years of graduated time, $9(33.3 \%)$ had from 11 to 20 years, and $8(29.7 \%)$ had from 21 to 40 years of graduated, 18 (66.7\%) of them had a master's degree, $8(29.6 \%)$ had a doctorate and 1 (3.7\%) had a specialization.

Table 1 presents the evaluation of judges using the Delphi technique on the characteristics of the IAD prevention and treatment algorithms. In the first evaluation, the judges assessed the algorithms as "partially adequate" to "fully adequate" and, after corrections were made on the basis of the judges' comments, the algorithms were sent back to the judges and assessed as "adequate" and "fully adequate". 


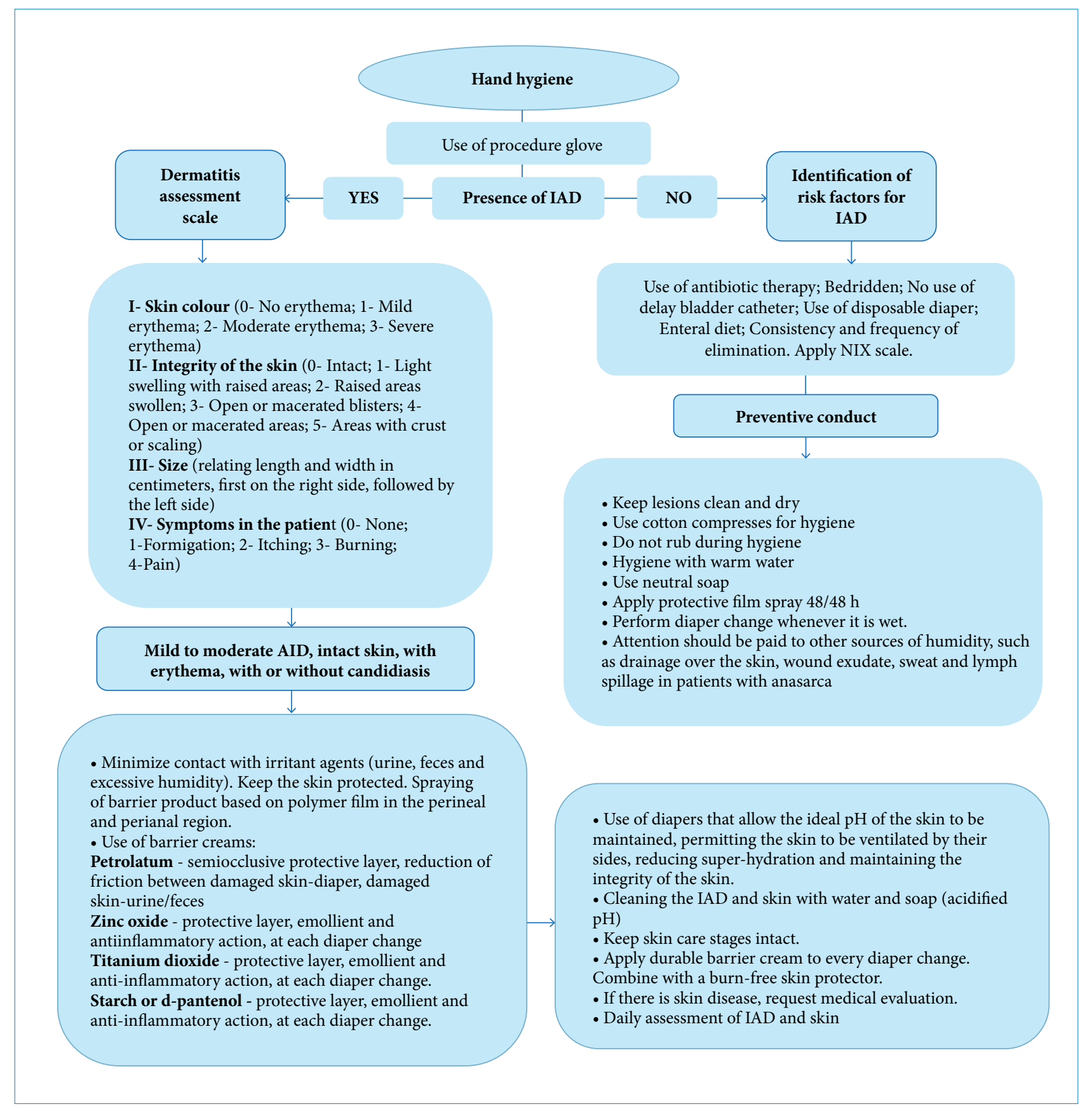

Figure 3. Algorithms for the prevention and treatment of incontinence associated dermatitis. Pouso Alegre, MG, Brazil, 2019.

Table 1. Evaluation of the content of the algorithms by the judges, according to the Delphi technique. Pouso Alegre, MG, Brazil, 2019.

\begin{tabular}{|c|c|c|c|c|c|c|c|c|c|c|}
\hline \multirow{2}{*}{$\begin{array}{c}\text { Questions } \\
\text { First evaluation }\end{array}$} & \multicolumn{2}{|c|}{ Inadequate } & \multicolumn{2}{|c|}{$\begin{array}{c}\text { Partially } \\
\text { adequate }\end{array}$} & \multicolumn{2}{|c|}{ Adequate } & \multicolumn{2}{|c|}{$\begin{array}{c}\text { Totally } \\
\text { adequate }\end{array}$} & \multicolumn{2}{|c|}{ Total } \\
\hline & $\mathrm{N}$ & $\%$ & $\mathrm{~N}$ & $\%$ & $\mathrm{~N}$ & $\%$ & $\mathrm{~N}$ & $\%$ & $\mathrm{n}$ & $\%$ \\
\hline Graphical presentation & 0 & 0 & 2 & 7.4 & 7 & 25.9 & 18 & 66.7 & 27 & 100 \\
\hline Ease of reading & 0 & 0 & 3 & 11.1 & 8 & 29.6 & 16 & 59.3 & 27 & 100 \\
\hline Sequence of algorithms & 0 & 0 & 0 & 0.0 & 7 & 25.9 & 20 & 74.1 & 27 & 100 \\
\hline
\end{tabular}


Table 1. Continuation...

\begin{tabular}{|c|c|c|c|c|c|c|c|c|c|c|}
\hline \multirow{2}{*}{$\begin{array}{c}\text { Questions } \\
\text { First evaluation }\end{array}$} & \multicolumn{2}{|c|}{ Inadequate } & \multicolumn{2}{|c|}{$\begin{array}{l}\text { Partially } \\
\text { adequate }\end{array}$} & \multicolumn{2}{|c|}{ Adequate } & \multicolumn{2}{|c|}{$\begin{array}{c}\text { Totally } \\
\text { adequate }\end{array}$} & \multicolumn{2}{|c|}{ Total } \\
\hline & $\mathrm{N}$ & $\%$ & $N$ & $\%$ & $\mathrm{~N}$ & $\%$ & $\mathrm{~N}$ & $\%$ & $\mathrm{n}$ & $\%$ \\
\hline Vocabulary & 0 & 0 & 2 & 7.4 & 10 & 37.0 & 15 & 55.6 & 27 & 100 \\
\hline $\begin{array}{l}\text { Clarity and understanding of } \\
\text { information }\end{array}$ & 0 & 0 & 3 & 11.1 & 11 & 40.7 & 13 & 48.1 & 27 & 100 \\
\hline Definition of IAD & 0 & 0 & 1 & 3.7 & 8 & 29.6 & 18 & 66.7 & 27 & 100 \\
\hline Description of risk factors for IAD & 0 & 0 & 4 & 14.8 & 7 & 25.9 & 16 & 59.3 & 27 & 100 \\
\hline $\begin{array}{l}\text { Description of the NIX's perineal } \\
\text { assessment scale }\end{array}$ & 0 & 0 & 1 & 3.7 & 6 & 22.2 & 20 & 74.1 & 27 & 100 \\
\hline $\begin{array}{l}\text { Description of the items of } \\
\text { therapeutic conduct }\end{array}$ & 0 & 0 & 2 & 7.4 & 9 & 33.3 & 16 & 59.3 & 27 & 100 \\
\hline $\begin{array}{l}\text { Description of the IAD assessment } \\
\text { scale }\end{array}$ & 0 & 0 & 1 & 3.7 & 5 & 18.5 & 21 & 77.8 & 27 & 100 \\
\hline $\begin{array}{l}\text { Therapeutic conduct for the } \\
\text { treatment of IAD }\end{array}$ & 0 & 0 & 4 & 14.8 & 5 & 18.5 & 18 & 66.7 & 27 & 100 \\
\hline Second evaluation & $\mathrm{N}$ & $\%$ & $\mathrm{~N}$ & $\%$ & $\mathrm{~N}$ & $\%$ & $\mathrm{~N}$ & $\%$ & $\mathrm{n}$ & $\%$ \\
\hline Graphical presentation & 0 & 0 & 0 & 0 & 7 & 25.9 & 20 & 74.1 & 27 & 100 \\
\hline Ease of reading & 0 & 0 & 0 & 0 & 8 & 29.6 & 19 & 70.4 & 27 & 100 \\
\hline Sequence of algorithms & 0 & 0 & 0 & 0 & 7 & 25.9 & 20 & 74.1 & 27 & 100 \\
\hline Vocabulary & 0 & 0 & 0 & 0 & 10 & 37.0 & 17 & 63.0 & 27 & 100 \\
\hline $\begin{array}{l}\text { Clarity and understanding of } \\
\text { information }\end{array}$ & 0 & 0 & 0 & 0 & 11 & 40.7 & 16 & 59.3 & 27 & 100 \\
\hline Description of risk factors for IAD & 0 & 0 & 0 & 0 & 9 & 33.3 & 18 & 66.7 & 27 & 100 \\
\hline $\begin{array}{l}\text { Description of the NIX's perineal } \\
\text { assessment scale }\end{array}$ & 0 & 0 & 0 & 0 & 6 & 22.2 & 21 & 77.8 & 27 & 100 \\
\hline $\begin{array}{l}\text { Description of the items of } \\
\text { therapeutic conduct }\end{array}$ & 0 & 0 & 0 & 0 & 9 & 33.3 & 18 & 66.7 & 27 & 100 \\
\hline $\begin{array}{l}\text { Description of the IAD assessment } \\
\text { scale }\end{array}$ & 0 & 0 & 0 & 0 & 5 & 18.5 & 22 & 81.5 & 27 & 100 \\
\hline $\begin{array}{l}\text { Therapeutic conduct for the } \\
\text { treatment of IAD }\end{array}$ & 0 & 0 & 0 & 0 & 8 & 29.6 & 19 & 70.4 & 27 & 100 \\
\hline
\end{tabular}

$\mathrm{IAD}=$ incontinence-associated dermatitis.

It is possible to verify in Table 2 that there was no agreement by the judges in the first evaluation, and the index of validity of the content varied between 0.889 and 0.923 ; in the second evaluation, however, there was agreement by the judges in all items and the index of validity of content was 1.0 . 
Table 2. Content validity index for the first and second evaluations. Pouso Alegre, MG, Brazil, 2019.

\begin{tabular}{|c|c|c|}
\hline \multirow{2}{*}{ Questions } & \multicolumn{2}{|c|}{ CVI } \\
\hline & First evaluation & Second evaluation \\
\hline Graphical presentation & *0,926 & $\star 1,000$ \\
\hline Ease of reading & 0,889 & $* 1,000$ \\
\hline Sequence of algorithms & $\star 1,000$ & $\star 1,000$ \\
\hline Vocabulary & *0,926 & $\star 1,000$ \\
\hline Clarity and understanding of information & 0,889 & *1,000 \\
\hline Definition of incontinence-associated dermatitis & $*_{0,963}$ & $\star 1,000$ \\
\hline Description of risk factors for incontinence-associated dermatitis & 0,852 & $* 1,000$ \\
\hline Description of the NIX's perineal assessment scale & *0,963 & $\star 1,000$ \\
\hline Description of the items of therapeutic conduct & *0,926 & $\star 1,000$ \\
\hline Description of the scale for assessing incontinence-associated dermatitis & *0,963 & $* 1,000$ \\
\hline Therapeutic conduct related to the treatment & 0,852 & $\star 1,000$ \\
\hline General CVI & $\star 0,923$ & $\star 1,000$ \\
\hline
\end{tabular}

$\mathrm{CVI}=$ content validity index; ${ }^{*} \mathrm{CVI} \geq 0.90$.

\section{DISCUSSION}

It was chosen to elaborate the algorithms, because they are graphical maps used to better visualize the components and processes of a problem. Clinical algorithms enable correct steps in the evolution of a specific subject in patient care. Algorithms have been developed to care for, direct, guide clinical decisions, care and treatment of skin lesions. They are validated studies and results of recommendations based on scientific evidence of care practice $^{7,12,13,20,21}$

The choice of the theme "algorithm for prevention and treatment of IAD" arose from the difficulties of researchers in their academic and welfare activities in finding criteria for prevention and treatment. Often, it is verified the action of the professional doing hygiene of the genital, perigenital and intimate perineal areas with improper soap, use of two diapers and treatment of the lesion by means of mixture of oils with ointments or cream.

Faced with the need to implement care, the algorithm initially involves the assessment steps consisting of physical examination, identification of risk factors for the individual to acquire the IAD and also the application of the perineal assessment tool scale. If the presence of dermatitis is not identified, algorithms suggest the care and products that should be used daily in the hygiene of the genital, perigenital and perineal areas for the prevention of IAD. If the presence of dermatitis is identified, the algorithm offers the therapeutic conducts.

In the health area, algorithms must be constructed with clear and easy-to-understand words and techniques, as they are essential instruments for quality care management. The algorithm should cover all steps of the procedure and help the nurse in providing quality care and decision making, especially when these are complex, providing safety for the patient ${ }^{8,14,17}$.

After the literature review, the algorithms were constructed and sent to the judges to evaluate. In the first evaluation, there were several suggestions related to preventive measures and therapeutic conducts. The adjustments suggested by the judges were made and the algorithms were sent back to the second round of evaluation. In the second evaluation, there was consensus of approval among the judges (100\%).

The development of an algorithm for wound evaluation should be carried out on a scientific basis, including articles 
with clinical evidence, in order to assist in technical, clinical, administrative and financial procedures, with the aim of improving patient care and reducing the treatment $\operatorname{cost}^{7,21-23}$.

During validation, the algorithm undergoes some important changes for its completion. These corrections contribute to a better understanding, effectiveness and implementation of the algorithm in the institution, enabling the professional to choose the most appropriate coverage for wound healing, resulting in an assistance with minimal risk, without damage and with a reduction in $\operatorname{cost}^{7,13,22}$.

A study whose objective was to elaborate an algorithm to support the nursing decision in coverage selection according to the type of injury and laser application indicated that $83.3 \%$ of the professionals considered important the application of this instrument to support the nursing decision in coverage selection and preventive measures, and that the algorithms should be developed with scientific basis ${ }^{12,13}$.

Based on the results of this study, it is believed that algorithms are able to guide professionals in making decisions to prevent and treat IAD. The judges had the opportunity to criticize the possible flaws in the algorithms in order to improve them. The criticisms were carefully analyzed by the researchers; those indicated as relevant were accepted and mentioned in the results of this study, those that would not add or that were not related to the proposal of the present study and those that did not present clinical evidence were discarded and, consequently, not mentioned in the study.

The elaboration and structuring of the algorithm is a technology formulated from scientific evidence to support evidence-based practice that guides the health care team in making decisions, provides a broad view of a whole process and facilitates the management of nursing care. Algorithms should be evaluated for effectiveness and functionality by the nursing team after their construction, in order to consider the adoption of the algorithm by professionals ${ }^{23-25}$.

Algorithms, flowcharts, protocols, booklets, manuals and guidelines are considered important tools for addressing various problems in health care and health service management. Studies validated by scientific evidence have technical, organizational and political guidelines as a basis. They also focus on the standardization of clinical, surgical and preventive procedures. The development of new tools requires the incorporation of new technologies that meet the needs for treatment as well as for health care organizations ${ }^{7,10,23,24}$.

The algorithms developed offer theoretical and practical basis to health professionals and contribute to the standardization of evaluation, hygiene in the genital, perigenital and perineal areas, standardization of preventive measures and therapeutic conducts, resulting in improved individualized care. This instrument systematizes prevention and care without risk or harm to the patient.

\section{CONCLUSION}

This study allowed the development of two algorithms and their validation by consensus among the group of evaluators. The constructed and validated algorithms present reliability for the objective evaluation of the genital, perigenital and perineal areas, and for the indication of hygiene procedures aiming at the prevention and treatment of IAD, besides facilitating the recording of the characteristics of IAD detected in patients, ensuring the monitoring of the evolution of the injury, minimizing risks, damages and adverse events. The algorithms also offer the healthcare professional the description of techniques, steps, information for managing care with quality and safety for the patient, and also seek to enable the professional a better visualization, practicality and understanding of the procedure to be performed.

\section{FUNDING}

Fundação de Amparo à Pesquisa do Estado de Minas Gerais [https://doi.org/10.13039/501100004901]

\section{AUTHOR'S CONTRIBUTION}

Conceptualization, Salomé GM, Rocha CA and Miranda FD; Methodology, Salomé GM, Rocha CA, Miranda FD, Alves JR and Dutra RAD; Investigation, Salomé GM, Rocha CA, Miranda FD, Alves JR, Dutra RAD and Tenório AG; Writing - Original Draft, Salomé GM, Rocha CA, Miranda FD, Alves JR, Dutra RAD and Tenório AG; Writing - Review and Editing, Salomé GM, Miranda FD and Alves JR; Resources, Salomé GM and Rocha CA; Supervision, Salomé GM. 


\section{REFERENCES}

1. Waidman MAP, Rocha SC, Correa JL, Brischiliari A, Marcon SS. O cotidiano do indivíduo com ferida crônica e sua saúde mental. Texto Contexto - Enferm. 2011;20(4):691-9. https:// doi.org/10.1590/S0104-07072011000400007

2. Cunha JB, Dutra RAA, Salomé GM. Elaboração de algoritmo para avaliação e tratamento de ferida. ESTIMA, Braz J Enterostomal Ther. 2018;16:e2018. https://doi. org/10.30886/estima.v16.524

3. Salomé GM, Almeida SA, Ferreira LM. Association of sociodemographic factors with hope for cure, religiosity, and spirituality in patients with venous ulcers. Adv Skin Wound Care. 2015;28(2):76-82. https://doi.org/10.1097/01. ASW.0000459844.07689.02

4. Casteli CPM, Conceição AP, Ayoub AC. Critérios para realização de curativo em paciente com infecção de órgão/ cavidade após cirurgia cardíaca. ESTIMA, BrazJ Enterostomal Ther. 2017;15(3):127-31. https://doi.org/10.5327/Z18063144201700030002

5. Chianca TCM, Gonçales PC, Salgado PO, Machado BO, Amorim GL, Alcoforado CLGC. Dermatite associada à incontinência: estudo de coorte em pacientes críticos. Rev Gaúcha Enferm. 2016;37(Esp):e68075. https://doi. org/10.1590/1983-1447.2016.esp.68075

6. Alves LAF, Santana RF, Cardozo AS, Souza TM, Silva CFR. Dermatite associada à incontinência e o uso não padronizado de fraldas geriátricas: revisão sistemática. ESTIMA, Braz J Enterostomal Ther. 2016;14(4):203-13. https://doi.org/10.5327/Z1806-3144201600040007

7. Carvalho MRF, Salomé GM, Ferreira LM. Construction and validation of algorithm for treatment of pressure injury. J Nurs UFPE online. 2017;11(10 Suppl):4171-83.

8. Gray M, Bliss DZ, Doughty DB, Ermer-Seltun JA, KennedyEvans KL, Palmer MH. Incontinence-associated dermatitis: a consensus. J Wound Ostomy Continence Nurs. 2007;34(1):4554. https://doi.org/10.1097/00152192-200701000-00008

9. Gray M, Giuliano KK. Incontinence-associated dermatitis, characteristics and relationship to pressure injury. J Wound Ostomy Continence Nurs. 2018;45(1):63-7.

10. Locks MOH, Santos SMA. Uso de fralda geriátrica em hospitais: solução ou problema? ESTIMA, BrazJ Enterostomal Ther. 2015;13(1):27-34.

11. Jordan J. Prevention of incontinence-associated dermatitis in people with dementia. J Neurosci Nurs. 2015;11(5):228-34. https://doi.org/10.12968/bjnn.2015.11.5.228

12. Cunha DR, Salomé GM, Massahud Junior MR, Mendes B, Ferreira LM. Development and validation of an algorithm for laser application in wound treatment. Rev Latino-Am Enfermagem. 2017;25:e2955. https://doi.org/10.1590/1518-8345.1998.2955

13. Santos AC, Dutra RAA, Salomé GM, Ferreira LM. Construction and internal reliability of an algorithm for choice cleaning and topical therapy on wounds.J Nurs UFPE online. 2018;12(5):680-5. https:// doi.org/10.5205/1981-8963-v12i5a230675p1250-1262-2018

14. Pott FS, Ribas JD, Silva OBM, Souza TS, Danski MTR, Marineli MJ. Algoritmo de prevenção e tratamento de úlcera por pressão. Cogitare Enferm. 2013;18(2):238-44. https://doi. org/10.5380/ce.v18i2.26085

15. Frongillo EA, Baranowski T, Subar AF, Tooze JA, Kirkpatrick SI. Establishing validity and cross-context equivalence of measures and indicators. J Acad Nutr Diet. 2019;119(11):181730. https://doi.org/10.1016/j.jand.2018.09.005

16. Bliss DZ, Gurvich OV, Mathiason MA, Eberly LE, Savik K, Harms S, et al. Prevention of incontinence-associated skin damage in nursing homes: disparities and predictors. West J Nurs Res. 2017;39(5):643-59. https://doi. org/10.1177/0193945916666065

17. Faro ACM. Técnica Delphi na validação das intervenções de enfermagem. Rev Esc Enferm USP. 1997;31(2):259-73. https://doi.org/10.1590/S0080-62341997000200008

18. Castro AV, Rezende M. A técnica Delphi e seu uso na pesquisa de enfermagem: revisão bibliográfica. REME Rev Min Enferm. 2009;13(3):429-34.

19. Lopes MVO, Silva VM, Araujo TL. Methods for establishing the accuracy of clinical indicators in predicting nursing diagnoses. Int J Nurs Knowl. 2012;23(3):134-9. https://doi. org/10.1111/j.2047-3095.2012.01213.x

20. Alves DFS, Almeida AO, Silva JLG, Morais FI, Dantas SRPE, Alexandre NMC. Translation and adaptation of the BatesJensen wound assessment tool for the Brazilian culture. Texto Contexto - Enferm. 2015;24(3):826-33. https://doi. org/10.1590/0104-07072015001990014

21. Beitz JM, Bates-Jensen B. Algorithms, critical pathways, and computer software for wound care: contemporary status and future potential. Ostomy Wound Manag. 2001;47(4):3340; quiz 41-2.

22. Stephen-Haynes J. Development of an algorithm as an implementation model for a wound management formulary across a UK health economy. J Wound Care. 2013;22(12):6928. https://doi.org/10.12968/jowc.2013.22.12.692

23. Salomé GM, Bueno JC, Ferreira LM. Multimedia application in a mobile platform for wound treatment using herbal and medicinal plants. J Nurs UFPE online. 2017;11(11 Suppl):4579-88.

24. Salomé GM, Ferreira LM. Developing a mobile app for prevention and treatment of pressure injuries. Adv Skin Wound Care. 2018;31(2):1-6. https://doi.org/10.1097/01. ASW.0000529693.60680.5e

25. Cunha JB, Dutra RAA, Salomé GM, Ferreira LM. Computational system applied to mobile technology for evaluation and treatment of wounds. J Nurs UFPE online. 2018;12(5):1263-72. https://doi.org/10.5205/1981-8963v12i5a230677p1263-1272-2018 